\title{
Tax Rates and Tax Evasion: Evidence from Missing Imports in Tanzania
}

\author{
Manamba Epaphra ${ }^{1}$ \\ ${ }^{1}$ Department of Accounting and Finance, Institute of Accountancy Arusha, Arusha, Tanzania \\ Correspondence: Manamba Epaphra, Institute of Accountancy Arusha, P. O. Box 2798, Arusha, Tanzania. Tel: \\ 255-754-399-775. E-mail:emanamba@iaa.ac.tz or emalugu_007@yahoo.com
}

Received: November 10, 2014

Accepted: November 21, 2014

Online Published: January 25, 2015

doi:10.5539/ijef.v7n2p122

URL: http://dx.doi.org/10.5539/ijef.v7n2p122

\begin{abstract}
Tax evasion is the basic characteristic of many developing countries. De facto tax collections are consequently far below revenue implied by published or de jure tax rates. This paper empirically examines tax rates (tariff plus VAT rates) as the determinants of customs revenue evasion across products, based on a systematic analysis of discrepancies in trade declarations for trading partners, United Republic of Tanzania, Republic of South Africa and China. The results indicate that trade gap is highly correlated with tax rates, that is, much more value is lost for products with higher tax rates. The results also show that the trade gap is correlated with tax rates on closely related products from Republic of South Africa, implying that evasion takes place through misclassification of imports from higher-taxed categories to lower-taxed ones. However, there is no evidence of misclassification of imports from China. The wide divergences between the effective and statutory tax rates in Tanzanian tax system indicate that there is a scope for raising tax revenue without increasing tax rates by reinforcing tax and customs administrations and reducing tax evasion.
\end{abstract}

Keywords: tax evasion, imports, tariff rate, and import VAT

\section{Introduction}

Underground economies are considered to characterize most less developing countries (LDCs)(Johnson et al., 1997, 1998). According to Schneider and Enste (2000) during the 1994-1995 period, the underground economy in LDCs was 39 percent of GDP, compared to 35 percent of GDP in countries of the former Soviet Union, and 20.9 percent in Eastern Europe. On average, the size of the informal economy in Africa in 2010 was estimated at 40.3 percent of GDP (Schneider et al., 2010). In Tanzania, the underground economy is estimated at 56.4 percent, a figure that is closely similar to 58.3 percent in Zimbabwe, and 55.2 percent in Nigeria (Figure 1).

The underground economy in Tanzania and most other LDCs is, among others, characterized by unreported and/or underreported legal activities (Johnson et al., 1997, 1998). The general accepted reason for existence and flourish of underreporting is to avoid high tax rates. The prohibitive high tax rates are argued to force firms to hide their activities in the "shadow". Other causes of unreported and/or underreported activities include predatory behaviour of government officials, escaping extortion by criminal gangs, and inadequacy of institutional environment or weak contract enforcement (Johnson et al., 1999).

The purpose of this paper is to examine the relationship between official tax rates and tariff evasion in Tanzania. The paper quantifies the effects of official tax rates on tariff evasion by examining the relationship in Tanzania between the tariff schedule and the evasion gap defined as the difference between exporting countries' reported exports to Tanzania at the product level and Tanzania's reported imports from exporting countries (Note 1). The paper provides a framework for policy makers to know the significant relationship between tax rates and evasion in evaluation of alternative tax policies because tax rates are instruments that can be manipulated for policy goals and because that rate changes may have a substantial impact on evasion. 


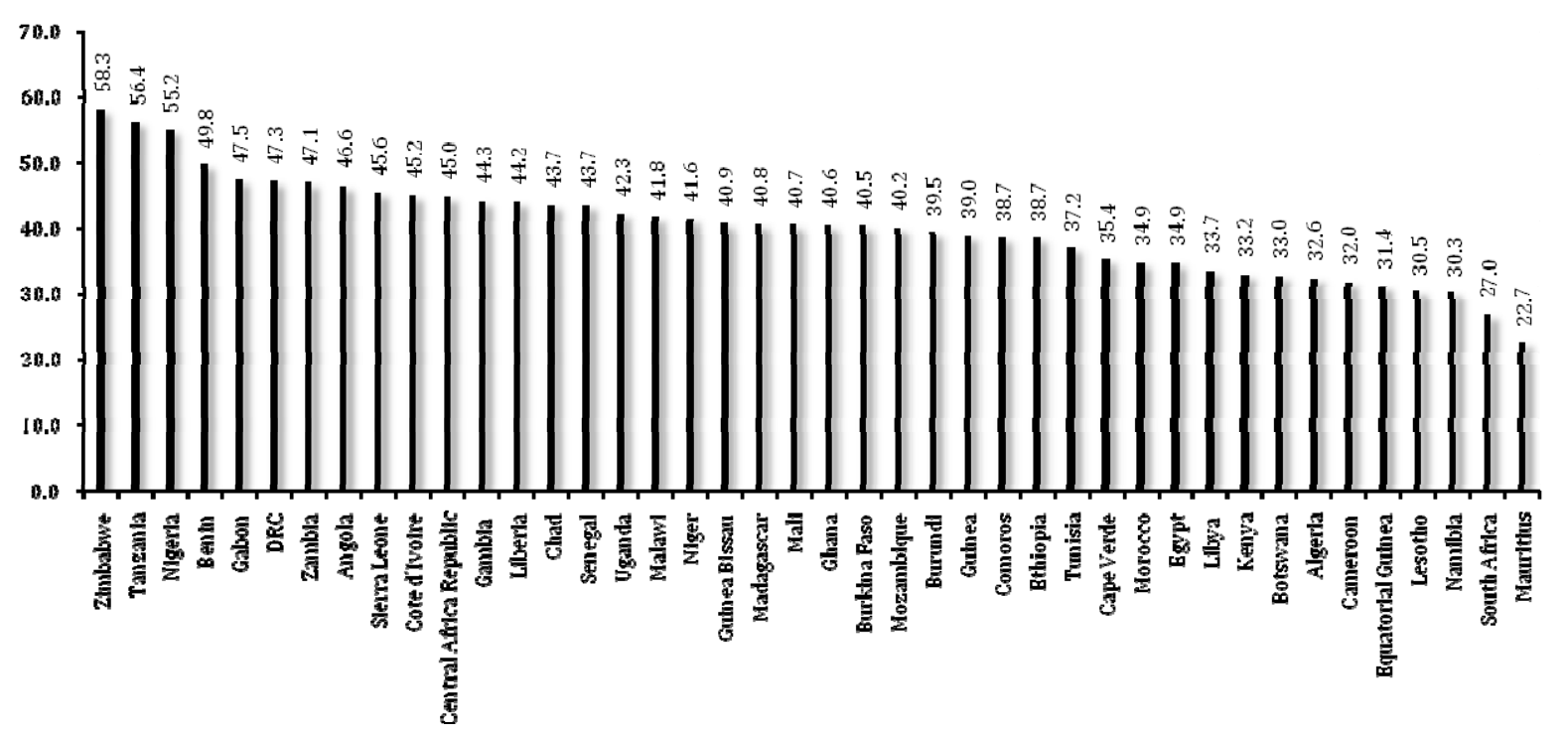

Figure 1. Shadow economy in Africa (Percent of GDP), 2010 (ranked by total tax evaded)

Note. Data on the size of shadow economies came from a World Bank working paper; by Friedrich Schneider, Andreas Buehn and Claudio E. Montenegro. Published in July, 2010.

\section{Tax Rates, Undervaluation of Imports and Tax Effort}

It is widely recognized that one of the objectives of tax reforms is to improve the efficiency of the tax administration and hence reduce tax evasion. Although the empirical evidence is mixed it seems that tax reform measures in some developing countries have not helped to reduce tax evasion (Fjeldstad \& Rakner, 2003). One important area where tax evasion has been reported to be a severe problem in sub-Saharan Africa (SSA) is customs duties (Levin \& Widell, 2007). For example, study by Arndt and Tarp (2003) on efficiency and equity gains from trade policy reforms in Mozambique shows that actual tariff revenue in 1997 was slightly less than 40 percent of the level projected by the de jure tariff rate and estimated import volume. A study by Mpango (1996) shows that the magnitude of deliberate aggregate under-invoicing of imports in Tanzania is about 20 percent induced by high scheduled tariff rates, vigorous exchange rate adjustment, low salaries and minimum incentives offered to the customs staff.

Moreover, the confederation of Tanzania industries (CTI) shows that the value of lost revenues from customs and sales tax due to misclassification and undervaluation of imported goods amounted to more than Tshs. 250 billion for the period between March 1993 and March 1994 (Osoro et al., 1999). Official statistics on reported revenue from customs duties also indicate substantial leakages. While the most prevalent official customs duties in the 1993-2011 period were between 6.6 and 18 percent, the reported duties as a percent of official import value were between 4.5 and 11.6 per cent (Table 1). In the years 1993, 2006, and 2010 this figure fell below 5 per cent. A significant positive relationship between tax evasion and tariff rates is reported by many studies, and the argument has been that as tariff rates increase, the proportion of official rates that is actually collected falls (Note 2).

The Government of Tanzania expected that reduced statutory rates would contribute to reduced tax evasion and therefore raise tax revenue; however, the wide divergences between the collected tariff rates and statutory tax rates in the Tanzanian tax system indicate that tax evasion is still an endemic problem, which appears to be substantial and widespread. A major problem in this respect is undervaluation of imported goods, which applies to most own-funds imports. This is due to the fact that the importer has access to foreign exchange without going through Bank of Tanzania records. Moreover, administrative constraints and corruption at entry points increase the problem of undervaluation of imported goods (Basu \& Morrissey, 1993).

As Tanzania and other low-income countries rely on trade taxes as an important source of revenue, evasion of import duties has attracted a lot of attention from policy makers. Estimates of this missing revenue are almost invariably large enough to be of macroeconomic interest. An IMF's staff review of various countries' experiences finds that nearly half of the low-income countries that cut their tariff rates due to trade liberalization, and suffered an associated revenue loss, recovered less than 70 percent of the lost revenue from other sources (IMF 
survey, 2005). This finding is consistent with the stylized fact that tax evasion and a large informal sector limit the amount of revenue government can rise from other sources (Acharya, 1985; de Soto, 1989; Bearser et al., 2000).

Table 1. Statutory tariff rates and collected tariff rates, 1993-2011

\begin{tabular}{lccc}
\hline & Statutory Tariff Rate & Collected Tariff Rate & Difference between Statutory and Collected Tariff rates \\
\hline 1993 & 15.6 & 4.5 & 11.1 \\
1997 & 18.3 & 9.7 & 8.6 \\
1998 & 18.3 & 11.6 & 6.7 \\
2000 & 13.1 & 8.3 & 4.8 \\
2001 & 12.4 & 8.8 & 3.6 \\
2002 & 9.2 & 6.6 & 2.6 \\
2003 & 8.2 & 7.4 & 0.8 \\
2005 & 8.4 & 6.6 & 1.8 \\
2006 & 7.2 & 4.0 & 3.2 \\
2007 & 7.2 & 5.2 & 2.0 \\
2008 & 10.9 & 5.1 & 5.8 \\
2009 & 10.8 & 5.1 & 5.7 \\
2010 & 8.2 & 4.5 & 3.7 \\
2011 & 6.6 & 5.0 & 1.6 \\
\hline
\end{tabular}

Sources: Based on data from the Tanzania Revenue Authority and Bank of Tanzania.

Tanzania's tax effort compares unfavourably to many other sub-Saharan African countries. Figure 2 shows that some countries collect as little as half of what they would be expected to, while others collect up to 2 to 3 times what they would be expected to. Twenty-four countries have a tax effort index (including resource-related tax revenues) higher than 1. Eighteen countries (out of 42 African countries) including Tanzania have indices lower than 1. A low tax effort ratio, below one, indicates that Tanzania is collecting less tax than predicted.

The slow growth in the overall revenue in Tanzania has raised serious concerns over the years. The tax system fails to capture potential revenues from economic activities due to the size and fast growth of the informal sector. The economy of Tanzania is mainly characterized by low per capita income and based on subsistence agriculture, which is difficult to tax. The formal sector, which is generally easier to tax, is limited to some large scale farms producing agricultural products for export, minerals, and some large manufacturing enterprises such as for beer, non-alcoholic drinks, tobacco, and other commodities. However, to the extent that the formal sector buys from informal sector, this may also impair tax administration (Ebrill et al., 1997). The presence of large inefficient state-owned enterprises also limits revenue collection. At the same time sluggish private sector growth has not generated enough revenue to compensate for revenue loss from the shrinking parastatal sector (World Bank, 1996). In addition to poor tax structure, Tanzania's tax system is characterized by weak tax and customs administration such as weak management practices and weak law enforcement, which impair efforts to raise revenue (Osoro, 1995; Fjeldstad, 2002).

The value of revenue loss from customs and other sources due to smuggling and undervaluation of imported goods is widespread in Tanzania where tax structure is exceedingly complex and tax administrative is weak. For example, customs revenue loss in 1993-1994 amounted to 2.5 times higher than reported customs revenue (Fjeldstad, 2002). According to ESRF (1996), official import statistics underreport the value of imports by as much as 70 percent. Gray et al. (2001), estimate that the magnitude of evasion of import taxes alone averages 2.1 percent of GDP.

The potential gain from involvement in tax evasion could be considerable both for officials and taxpayers. Relatively high rates and a complex and partly incoherent set of rules result in large potential rewards for taxpayers willing to bribe to cut their own tax burden and/or speed up customs clearance of their goods. For customs officials, the bribes taken for clearing specific containers in Dar es Salaam harbour could be as much as a whole year's salary (Fjeldstad, 2002). Maliyamkono and Bagachwa (1990) argue that, generally, high tax rates combined with deteriorating economic situation have tended to shift production towards those activities that are difficult to the tax net. In this connection, one can argue that the emergence of the underground economy has partly been a consequence of tax evasion (Osoro, 1995). 


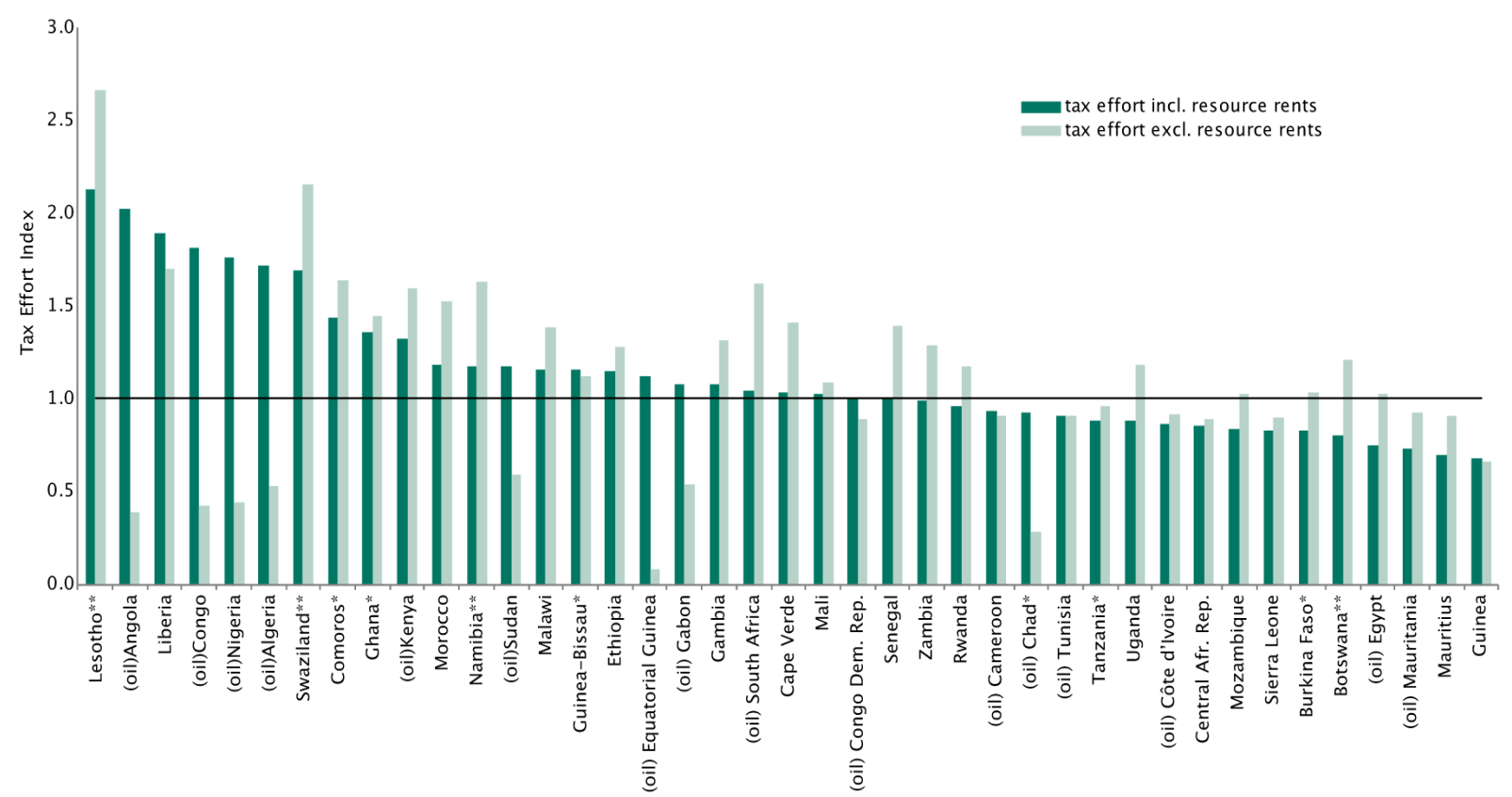

Figure 2. Tax effort across African countries in 2007

Note. (*) 2006 data , (**) The tax effort measures of Botswana, Lesotho, Namibia and Swaziland reflect their membership in the Southern African Customs Union (SACU), which collects customs duties centrally and redistributes them amongst members.

Source: AEO country surveys, 2010.

Despite quite comprehensive changes in tax structure (rates and bases) after 1998, the tax system in Tanzania is still complicated and relatively non-transparent (Osoro et al., 1999). Tax legislation is unclear and causes random and partly ad hoc collection procedures (Luoga, 2002). This situation is costly for enterprises and provides strong incentives to pay customs officers for a speedier service. Generally, inefficient customs operations such as long clearance times and complicated procedures act as dissipative trade barriers, which raise the costs of imports without generating revenues. Corruption and inefficiency are often two faces of the same coin as customs officers deliberately obstruct procedures in order to force traders to pay bribes. These are very serious issues, which help explain why countries having reformed their trade regimes but not their customs administration have sometimes failed to reap the full benefit of trade liberalization (Anson et al., 2003).

The double declaration of trade flows by importers and exporters offers an opportunity to gauge the importance of these unlawful practices; while evading customs duties generally requires the importers to sidestep import registration requirement, the situation is different for exporters. Bhagwati (1964) pioneered the use of discrepancies between "matched" declarations often at product level to reveal customs duties evasion. The result pointed to under-invoicing of import in Turkey. Following Fisman and Wei (2004), and Javocik and Narciso (2008), the differences between the country's reported value of imports from a partner country and the corresponding value of exports of the same product reported by the trading partner is termed as the trade gap (see equation 1).

$$
G V_{c p i t}=\log \left(E V_{p c i t}\right)-\log \left(I V_{c p i t}\right)
$$

where $G V_{c p i t}$ is a trade gap (evasion gap) in the importing country $c, I V_{c p i t}$ is the value of imports for country $c$ of product $i$ from a particular country $p$ at time $t$, and $E V_{c p i t}$ is the value of exports reported by a partner country $p$ to country $c$ of the same product.

The estimates of the evasion gap in Tanzania is presented in Table 2, using Tanzania's trade relations with her major trading partners, indicate positive values of the evasion gap for imports with higher tariff rates such as vegetables, food products, textile and clothing, stone and glass, footwear, and hides and skins. This can be attributed to under-invoicing and outright smuggling, which make importers evade customs duties. The high incidence of evasion, which is recorded in many of the commodities imported, suggests that customs administration is characterized by inefficiencies. It is estimated that in 2012 as much as 182.9 percent of textile and clothing, 277.4 percent of footwear, and 113.8 percent of hides and skins were not reported to the destination 
office (Table 3).

As the official trade statistics are delivered from the import and export declaration made by the dealers, there are at least five reasons why import value from importing country may differ from the corresponding exporting country. The first reason for major discrepancies in trade statistics is the undercount of export data which follows from exporters' failure to properly file export declarations. Some shippers do not file declarations due to lack of understanding of filling requirements while others simply do not bother to file. Studies show that enforcement for complying with import regulations is stricter than with exports regulations. The second major reason for a non-zero trade gap is related to transit trade with third countries. For example South Africa exporters passing their goods to Democratic Republic of Congo (DRC) through Tanzania may fail to declare the outbound movement from Tanzania, i.e. they may treat exports to DRC through Tanzania in the same way as they treat exports to Tanzania; such transactions may be captured as exports to Tanzania in South Africa statistics, while in Tanzania it will be classified as re-exports and will not be reflected in trade data with South Africa, thus leading to a positive Tanzania trade gap. The third source of discrepancies in trade statistics are the methodological differences between statistical agencies of importing country and exporting country. Each agency edits trade data according to its own procedure. As a result, differences in trade definition, currency conversions, valuation etc, can lead to an imbalance in trade statistics between the two countries.

The fourth reason for a trade gap to be different from zero is due to various actions undertaken by traders in order to avoid paying import duties. Fisman and Wei (2004) find that the Chinese trade gap with Hong Kong has a strong negative relationship with Chinese tariffs against imports from Hong Kong. Javorcik and Narciso (2008) find similar results for the German trade with Eastern European countries. In both studies, it is implicitly assumed that if the trade is driven by a measurement error only, it should be unrelated to any measure of trade policy. Thus, a statistical relationship between a trade gap and tariffs is interpreted as evidence of tariff evasion in countries with high trade barriers. Figure 3 (panels A-D) reports the correlation between trade gap and most favored nation (MFN) weighted average tariff rates for Tanzania's imports with its major trading partners. All panels reveal a positive association-ship between tariff evasion and tariff rates.

It is postulated in theory that changes in the official import tariff rate have both direct and indirect impact on customs revenue. Importers avoid paying import duties for commodities with high tariff rates. However, the interpretation of the estimated data on tariff evasion needs caution because of the possible inclusion of misclassified indirect imports in reported data (Fisman \& Wei, 2004, Brafu-Insaidoo \& Obeng, 2008). Part of indirect imports may be misclassified as direct imports. Moreover, the data as presented in Tables 2 and 3, and Figure 3 are on group commodity values and MFN weighted tariff rates, which may conceal accurate information on estimates for individual commodities and tariff rates. To avoid this problem regression analysis presented in section five uses individual countries' trade records that is recorded according to the Harmonized Commodity Description and Coding System (HS) at 6-digit category.

Table 2. Tanzania's major trading partners: estimated evasion gap, 2012

\begin{tabular}{|c|c|c|c|c|c|c|c|c|c|c|c|c|c|c|c|c|}
\hline \multirow[t]{2}{*}{ Product Group } & \multicolumn{3}{|c|}{ World } & \multicolumn{5}{|c|}{ China } & \multicolumn{3}{|c|}{$\begin{array}{c}\text { United Arab } \\
\text { Emirates }\end{array}$} & \multicolumn{5}{|c|}{ South Africa } \\
\hline & $\mathrm{EV}$ & IV & GV & $\begin{array}{l}\text { MFN } \\
\text { Tariff }\end{array}$ & $\mathrm{EV}$ & IV & GV & $\begin{array}{l}\text { MFN } \\
\text { Tariff }\end{array}$ & $\mathrm{EV}$ & IV & GV & $\begin{array}{l}\text { MFN } \\
\text { Tariff }\end{array}$ & $\mathrm{EV}$ & IV & GV & $\begin{array}{l}\text { MFN } \\
\text { Tariff }\end{array}$ \\
\hline Consumer Goods & 6.6 & 6.8 & -0.2 & 16.6 & 5.9 & 5.6 & 0.4 & 20.8 & 5.3 & 5.2 & 0.1 & 20.6 & 5.3 & 5.6 & -0.3 & 17.3 \\
\hline Capital Goods & 6.4 & 6.5 & -0.1 & 5.8 & 5.8 & 5.7 & 0.1 & 7.5 & 4.9 & 5.1 & -0.2 & 10.2 & 5.4 & 5.5 & 0.0 & 3.9 \\
\hline Intermediate Goods & 6.3 & 6.3 & -0.1 & 12.1 & 5.7 & 5.4 & 0.2 & 18.6 & 4.6 & 5.0 & -0.3 & 15.4 & 5.3 & 5.4 & -0.1 & 10.3 \\
\hline Machinery/Electricity & 6.3 & 6.3 & 0.0 & 6.9 & 5.2 & 5.5 & -0.3 & 10.1 & 4.8 & 5.0 & -0.2 & 12.3 & 5.4 & 5.0 & 0.4 & 5.6 \\
\hline Fuels & 6.1 & 6.6 & -0.4 & 0.7 & 3.3 & 3.9 & -0.6 & 3.6 & 4.3 & 4.3 & 0.0 & 20.6 & 4.4 & 5.4 & -1.0 & 3.6 \\
\hline Transportation & 6.0 & 6.1 & -0.2 & 7.3 & 5.1 & 5.4 & -0.3 & 6.1 & 4.7 & 4.8 & -0.1 & 10.7 & 4.7 & 5.0 & -0.2 & 8.1 \\
\hline Vegetables & 5.9 & 5.9 & 0.0 & 21.0 & 3.1 & 2.7 & 0.4 & 5.3 & 3.3 & 3.2 & 0.1 & 21.1 & 3.6 & 3.4 & 0.2 & 22.6 \\
\hline Chemicals & 5.8 & 5.9 & -0.1 & 4.2 & 5.0 & 5.0 & -0.0 & 3.9 & 4.1 & 4.7 & -0.6 & 14.0 & 4.6 & 4.7 & -0.1 & 11.3 \\
\hline Metals & 5.8 & 5.9 & -0.1 & 11.0 & 5.3 & 5.1 & 0.3 & 15.5 & 4.7 & 4.5 & 0.1 & 15.7 & 3.6 & 5.2 & -1.6 & 9.0 \\
\hline Textile /Clothing & 5.8 & 5.4 & 0.5 & 26.6 & 5.6 & 4.9 & 0.7 & 27.7 & 4.5 & 4.2 & 0.3 & 25.8 & 3.6 & 3.5 & 0.1 & 23.7 \\
\hline Plastic or Rubber & 5.7 & 5.8 & -0.1 & 14.3 & 5.3 & 5.1 & 0.2 & 15.5 & 4.5 & 4.4 & 0.1 & 16.9 & 4.6 & 4.7 & -0.1 & 6.9 \\
\hline Raw Materials & 5.7 & 5.6 & 0.0 & 14.3 & 3.5 & 3.7 & -0.2 & 8.2 & 3.4 & 3.4 & 0.0 & 16.4 & 4.2 & 4.0 & 0.2 & 14.6 \\
\hline Miscellaneous & 5.4 & 5.6 & -0.2 & 12.0 & 5.0 & 4.8 & 0.2 & 25.0 & 4.4 & 4.3 & 0.2 & 22.8 & 4.6 & 4.4 & 0.2 & 9.4 \\
\hline Food Products & 5.8 & 5.5 & 0.3 & 21.5 & 3.7 & 3.5 & 0.2 & 23.4 & 4.1 & 4.0 & 0.0 & 23.3 & 4.6 & 4.1 & 0.5 & 21.1 \\
\hline
\end{tabular}




\begin{tabular}{|c|c|c|c|c|c|c|c|c|c|c|c|c|c|c|c|c|}
\hline Wood & 5.3 & 5.3 & 0.1 & 14.8 & 4.7 & 4.4 & 0.3 & 22.8 & 4.0 & 3.7 & 0.3 & 19.2 & 4.6 & 4.5 & 0.1 & 19.6 \\
\hline Minerals & 5.3 & 5.1 & 0.2 & 25.9 & 4.6 & 4.7 & -0.0 & 2.3 & 2.7 & 3.2 & -0.6 & 9.7 & 2.8 & 2.7 & 0.1 & 4.7 \\
\hline Footwear & 5.2 & 4.6 & 0.6 & 24.3 & 5.1 & 4.3 & 0.8 & 24.4 & 3.8 & 3.6 & 0.2 & 24.6 & 3.3 & 3.1 & 0.2 & 23.3 \\
\hline Stone and Glass & 5.1 & 5.1 & 0.0 & 22.1 & 4.9 & 4.9 & 0.1 & 22.9 & 4.2 & 3.9 & 0.3 & 23.3 & 3.9 & 3.6 & 0.3 & 21.8 \\
\hline Animals & 4.6 & 4.4 & 0.1 & 44.3 & 3.2 & 2.6 & 0.6 & 25.0 & 3.3 & 3.0 & 0.2 & 32.7 & 3.5 & 3.4 & 0.1 & 54.4 \\
\hline Hides and Skins & 4.4 & 4.0 & 0.3 & 25.0 & 4.5 & 3.9 & 0.6 & 25.0 & 3.5 & 3.3 & 0.2 & 24.7 & 2.8 & 2.5 & 0.2 & 24.7 \\
\hline
\end{tabular}

Source: Author's estimations: Computed with data from World Bank's Integrated Trade Solutions (WITS) data base.

Table 3. Percent share of missing imports from major trading partners attributed to under-invoicing, 2012

\begin{tabular}{|c|c|c|c|c|c|c|c|c|}
\hline \multirow[t]{2}{*}{ Product Group } & \multicolumn{2}{|c|}{ World } & \multicolumn{2}{|c|}{ China } & \multicolumn{2}{|c|}{ UAE } & \multicolumn{2}{|c|}{ South Africa } \\
\hline & Group $^{1}$ & Total $^{2}$ & Group & Total & Group & Total & Group & Total \\
\hline Consumer Goods & -35.4 & -17.7 & 121.6 & 38.0 & 33.4 & 4.9 & -51.9 & -21.7 \\
\hline Capital Goods & -16.6 & -4.2 & 37.5 & 15.7 & -41.3 & -5.6 & -5.0 & -1.6 \\
\hline Intermediate Goods & -15.7 & -3.0 & 66.5 & 16.0 & -52.6 & -4.9 & -19.7 & -5.3 \\
\hline Machinery and Electricity & -4.9 & -0.8 & -46.6 & -11.6 & -42.1 & -4.7 & 169.0 & 16.8 \\
\hline Fuels & -64.3 & -21.0 & -72.4 & -0.4 & 5.3 & 0.1 & -91.0 & -25.1 \\
\hline Transportation & -31.6 & -3.7 & -43.8 & -9.0 & -18.4 & -1.3 & -41.1 & -4.1 \\
\hline Vegetables & 4.4 & 0.3 & 150.0 & 0.1 & -16.7 & 0.0 & 64.6 & 0.2 \\
\hline Chemicals & -15.9 & -1.1 & -1.6 & -0.2 & -75.1 & -4.0 & -11.4 & -0.6 \\
\hline Metals & -18.5 & -1.3 & 77.4 & 8.3 & 39.9 & 1.4 & -97.6 & -18.3 \\
\hline Textile and Clothing & 182.9 & 3.5 & 408.9 & 25.3 & 83.5 & 1.5 & 35.5 & 0.1 \\
\hline Plastic or Rubber & -26.0 & -1.5 & 65.9 & 7.0 & 38.7 & 0.9 & -11.5 & -0.6 \\
\hline Raw Materials & 9.4 & 0.4 & -35.6 & -0.2 & 10.1 & 0.0 & 56.9 & 0.7 \\
\hline Miscellaneous & -39.4 & -1.5 & 50.2 & 2.8 & 45.2 & 0.9 & 54.1 & 1.5 \\
\hline Food Products & -14.5 & -0.4 & 74.1 & 0.2 & 10.9 & 0.1 & 202.2 & 2.6 \\
\hline Wood & 21.8 & 0.3 & 93.4 & 1.9 & 100.8 & 0.5 & 27.3 & 1.0 \\
\hline Minerals & 61.7 & 0.6 & -1.6 & -0.1 & -72.7 & -0.1 & 22.8 & 0.0 \\
\hline Footwear & 277.4 & 0.9 & 484.0 & 9.1 & 52.3 & 0.2 & 53.0 & 0.1 \\
\hline Stone and Glass & -3.7 & 0.0 & 13.6 & 0.8 & 96.1 & 0.8 & 98.3 & 0.4 \\
\hline Animal & 29.6 & 0.1 & 252.0 & 0.1 & 74.3 & 0.1 & 23.3 & 0.1 \\
\hline Hides and Skins & 113.8 & 0.1 & 318.3 & 2.1 & 70.9 & 0.1 & 69.4 & 0.0 \\
\hline
\end{tabular}

Source: Author's estimations: Computed with data from World Bank's Integrated Trade Solutions (WITS) data base.

Note.1 Percent of respective product group. 2. Percent of total imports.

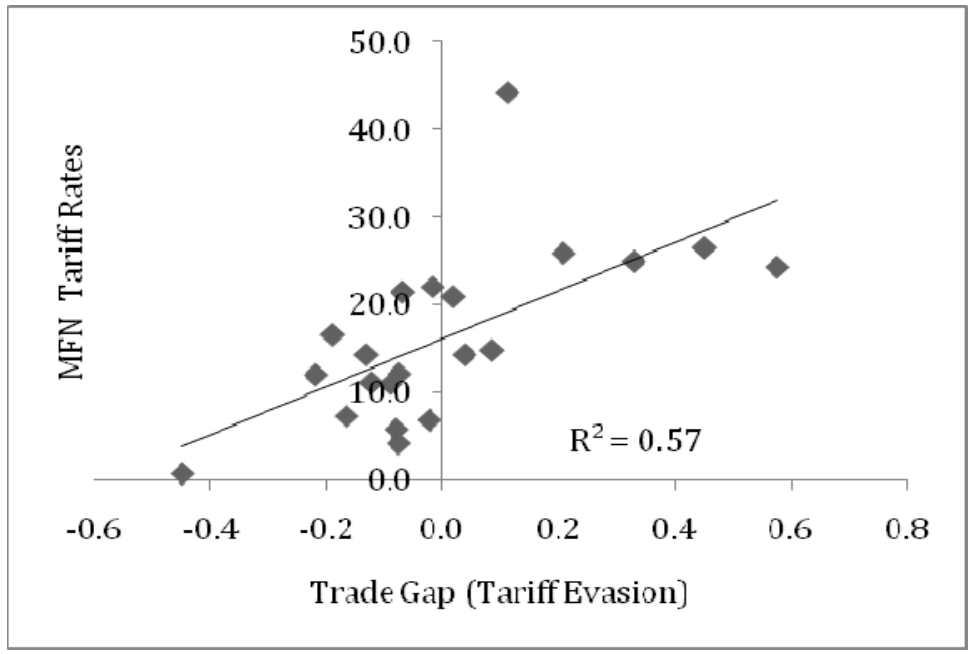

Panel A. Imports from all trading partners 


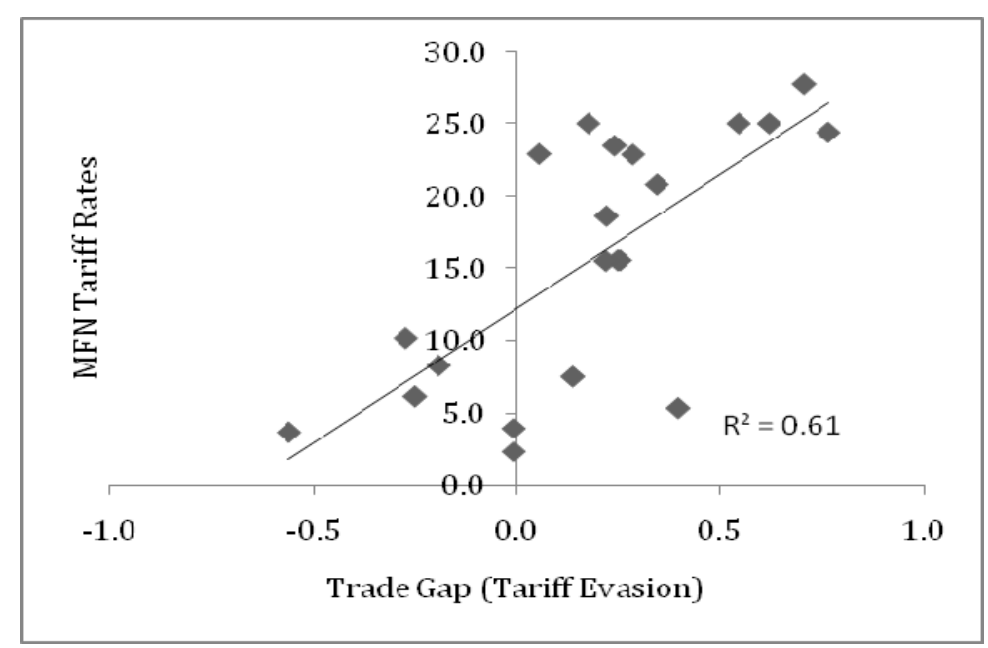

Panel B. Imports from China

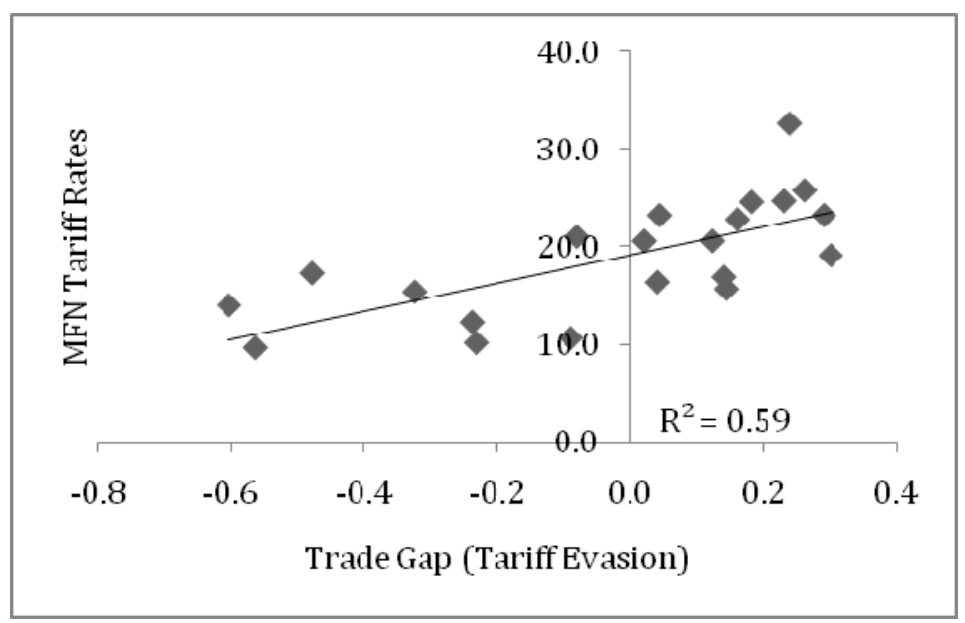

Panel C. Imports from United Arab Emirates

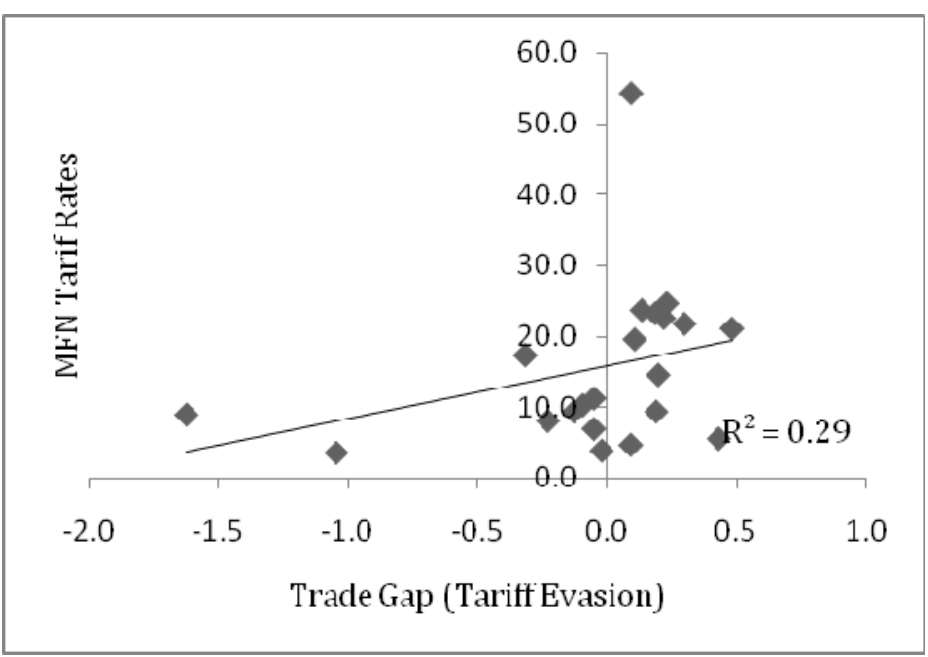

Panel D. Imports from South Africa

Figure 3. Scatter diagram

Source: Author's estimations: Computed with data from World Bank's Integrated Trade Solutions (WITS) data base and UNCTAD TRAINS. 


\section{Literature Review}

Tax evasion has been universal and persistent problem in every country in the world and should be considered a potential problem everywhere. However, tax evasion is a phenomenon that hits developing countries (Fjeldstad, 2002). McLaren (1996) characterizes the extent of tax evasion in general in LDCs as "staggering" and suggests that the value of taxes avoided is often close to the value of actual collections for major taxes.

Evidence from different developing countries indicates that the treasury due to corruption and tax evasion cannot trace half or more of the taxes that should be collected. This erosion of tax base has several detrimental fiscal effects. The consequences of lost revenue to the funding of public services are of special concern (Tanzi, 2003). In addition, it creates deadweight (allocative efficiency) loss on the economy (Harberger, 1964), and also undermines equity in taxation by shifting the burden in the direction of honest, socially responsible individual and corporations. Furthermore, a growing shadow economy gives rise to increasing segments of the money supply, which is uncontrolled, and thus undermines inflation policy. Any increase in the rate of inflation can also result in a significant long-term deadweight loss (Feldstein, 1996). So, it is important to have a proper understanding of the incentive structure that derives the behavior that shapes the temporal development of the shadow economy.

The incentive to avoid and evade taxes in response to an increasing tax burden has been long-recognized, the level of tax rate is linked to the security of the tax base, the higher are the taxes, the greater is the risk to the base. According to Gutmann (1977), higher taxes derive more and more of the economy underground, beyond the reach of the tax collector. The sign of relationship between the tax rate level and the amount of income declared by taxpayer, however, is the question still not satisfactorily resolved. In the pioneering model of Allingham and Sandmo (1972), the relationship between tax rates and evasion is ambiguous, and depends on the third derivative of the utility function. They show that for a risk-neutral individual maximization of expected utility implies that evasion will tend to increase with marginal tax rate. When risk aversion is allowed, however, they conclude that no clear-cut hypothesis emerges as to the connection between the regular tax rate and reported income. Furthermore, Yitzhaki (1974) summaries this analysis by showing that the tax rate in Allingham and Sandmo (1972)'s model has a substitution effect favoring evasion and an income effect discouraging it and that the net effect is uncertain. Though the theoretical ambiguity remains for the relationship between tax rates and evasion, Bhagwati (1964) explicitly links up the discrepancies between import data of Turkey and the export data of her partner countries and suggests that the discrepancies between a country's reported imports and the corresponding exports reported by its trading partners may be explained by the undervaluation or misclassification of imports at the border in order to reduce the tariff burden.

Pritchett and Sethi (1994) examine the correlation between the tariff rates using data from Jamaica, Kenya, and Pakistan and find a weak relationship between the de facto tariff rates, calculated by dividing tariff revenue with import values for each product, and the statutory rates. This nonlinear relationship between collected rates and statutory tariff rates indicates that incentives for misreporting increase with higher tariff rate. Fisman and Wei (2004) examine bilateral trade data between Hong Kong and China in an attempt to identify the effect of tax rates on tax evasion, and they note that the evasion gap is highly correlated with tax rates. According to their findings, tariff rate declines, particularly for highly taxed items, would result in substantial increases in revenue. They conclude that practice such as under-reporting import unit values and mislabeling higher-taxed products, as lower-taxed categories are widespread.

Van Dunem and Arndt (2009) using the same approach for the case of Mozambique find an elasticity half as large as in Chinese case. Applying the same approach to trade between Germany and ten Eastern European countries in 1992-2007, Javorcik and Narciso (2008) find support for the hypothesis that higher product-level tariffs spur higher levels of tariff evasion with estimated elasticities that tend to be weaker than those found by Fisman and Wei (2004). Javorcik and Narciso (2008) also show that the relationship between reporting discrepancies and tariffs is stronger for differentiated products, which they explain by the greater ease to conceal the real value of goods when they are differentiated, as also suggested by Bhagwati (1967).

These empirical studies suggest that customs duty evasion due to high tariffs is not specific to a few countries, however, given the nature of imports and export data, the assumption of trade gap (tariff evasion) implies that countries with high tariffs, traders would tend to under-report the value of imports at the destination country and report the true value of exports at the source country. Are there any reasons to believe that smugglers truthfully report their export declaration? Until it is known how a trade gap and import tariffs are related to a firm's incentive to report its imports and exports, we cannot be sure that the relationship between trade gap and tariffs, found in previous studies pertains to tariff evasion. As it turns out firms incentives to report imports and exports 
truthfully vary across countries, depending on the systems of trade control, penalties for misreporting, and trade law enforcement.

Understanding of the relationship between tax rates and customs revenue evasion is important for policy formulation and implementation of further trade reforms, however, evasion of customs revenues has captured little attention compared with other forms of taxes. The lack of attention is due to the fact that most of the research on revenue has been carried out in the developed world where customs revenues occupy a marginal role in the revenue structure of the economy. In developing countries however, international trade offers the only reliable base for levying taxes since the formal sector is not large enough to warrant adequate amount of direct taxes. Hence the trade-sector becomes the niche sector of the economy for mobilization of resources. Thus, the study on tariff evasion in Tanzania is of great importance. In addition, since several studies show that there is an ambiguity about the direction of the impact of the level of tax rate on tax evasion as well as the problems of measurement of evasion, this paper explores the correlation between tax rates (tariff and import VAT rates) and tariff revenue evasion for Tanzania, using the reporting gap between exporting and importing country agencies.

\section{Methodology of the Study}

\subsection{Estimation Model}

The analysis in this paper is based on the methodology used by Fisman and Wei (2004). The methodology is preferred because of the fact that other indirect approaches such as currency demand, and discrepancies between national expenditure and income statistics (Guttmann, 1977, Feige, 1979, Tanzi, 1980) do not naturally generate an estimate of the responsiveness of tax evasion (trade gap) to changes in tax rate (Fisman \& Wei, 2004). They also may not be suitable for studying tax evasion in the non-monetized economy such as Tanzania. Since, China's and South Africa's exports to Tanzania accounts for the main imports of Tanzania, the paper examines evasion in Tanzania's imports from China and South Africa, at a disaggregated level, by comparing China and South Africa reported exports and Tanzania reported imports of the same products. In the absence of evasion (and measurement error), Tanzania and China and South Africa-reported numbers should be the same.

The trade gap is measured as the differences between the value of exports from China and South Africa in each product in a sample as reported by China and South Africa (the exporting countries), and the value of imports from China and South Africa as reported by Tanzania (the importing country) (Note 3). In other words, for every product that Tanzania imports from China and South Africa, the export value $(E V)$ is defined as the value reported by China and South Africa and the import value $(I V)$ as that value reported by Tanzania. Furthermore, export quantity $(E Q)$ is defined as the total quantity of exports reported by China and South Africa and import quantity $(I Q)$ as the total quantity of imports reported by Tanzania. The basic definition of the evasion gap is therefore expressed as

$$
G V_{t, k}=\log \left(E V_{t, k, C \text { or } S}\right)-\log \left(I V_{t, k, T}\right)
$$

where $G V=$ Evasion Gap in Values;

$t=$ time;

$k=$ product;

Cor $S=$ China or South Africa;

$T=$ Tanzania .

Thus, defined, a larger gap is an indication of greater evasion. Similarly, the gap in quantities reported is expressed as

$$
G Q_{t, k}=\log \left(E Q_{t, k, C \text { or } S}\right)-\log \left(I Q_{t, k, T}\right)
$$

where $G Q=$ Evasion Gap in Quantities.

The basic issue that is examined in the empirical test is whether the difference between exports and imports is increasing in the tax rates, due to evasion. That is

$$
G V_{t, k}=\lambda_{0}+\lambda_{1} \text { Taxrate }_{t, k}+\varepsilon_{t, k}
$$

where $\lambda_{0}$ is a constant, and $\varepsilon_{k}$ a composite error term that is assumed to be independent and identically distributed (iid) and normal with a mean of zero and a constant variance. A sub index $k$ denotes product and Taxrate denotes product specific tax rates (tariffs plus value added tax rates, where tariffs include import duties and excise duties) in Tanzania. The expectation is $\lambda_{1}>0$ if evasion is induced by tax rate. If, for example, $\lambda_{1}=0.2$, it will imply that the gap between reported exports and imports increases by 0.2 percent if the tax rate increases by one percent 
point. However, if the idea that higher tariffs encourage fraud sounds plausible a priori, the relationship may not, as a matter of fact, be so clear-cut (Anson et al., 2003). Anson et al. (2003) state that categories of goods with high tariffs may be those most carefully scrutinized by customs so trying to evade in those categories may be just the wrong thing to do. Indeed, the relationship between tax rates and tax evasion can theoretically go either way (Slemrod \& Yitzhaki, 2000).

Due to the fact that part of tax evasion does not only take the form of underreporting but also of mislabeling imported products from a higher-taxed to a lower-taxed type, Fisman and Wei (2004) assume that this type of mislabeling is easier for similar products, and therefore, define $\operatorname{Avg}\left(\operatorname{Tax} \_\right)$as the average level of tax rate of all other products in a goods 4-digit class. Adding the average tax variable to the right hand side of equation (4), the following regression function is implemented

$$
G V_{t, k}=\lambda_{0}+\lambda_{1} \text { Taxrate }_{t, k}+\varepsilon_{t, k}+\lambda_{2} \text { Avg }\left(\text { tax } \_o\right)_{t, k}+\varepsilon_{t, k}
$$

If evasion by mislabeling of goods is prevalent, one would expect $\lambda_{2}<0$, that is, holding a product's own tax rate constant, the lower the tax rate on product $k$ 's similar varieties, the greater the incentive for mislabeling the import of product $k$ as other similar products.

So far we have dealt with evasion in values, but evasion in quantities by underreporting may also be common. For that case, the following regression functions are also investigated

and

$$
G Q_{t, k}=\lambda_{0}+\lambda_{1} \text { Taxrate }_{t, k}+\varepsilon_{t, k}
$$

$$
G Q_{t, k}=\lambda_{0}+\lambda_{1} \text { Taxrate }_{t, k}+\varepsilon_{t, k}+\lambda_{2} \text { Avg }\left(\text { tax }_{-} o\right)_{t, k}+\varepsilon_{t, k}
$$

If under-reporting in quantities is established, one would expect $\lambda_{1}>0$ in the quantity regression (7) and if there is mislabeling of the imports from a higher-taxed type to a lower-taxed one, one would expect $\lambda_{1}>0$ and $\lambda_{2}<0$.

\subsection{Reliability of Data and Some Measurement Errors}

A central challenge when studying the tax evasion concerns the issue of measurements. By its very nature, like all forms of fraud, tariff evasion cannot be measured directly, so roundabout methods must be applied (Anson et al., 2003). The most common one consists of comparing the records of exporting country and importing country. Traders attempting to evade import tariffs will under-invoice the value of shipments to destination customs while no incentive exists at origin ones (Anson et al., 2003). A discrepancy between the value of exports recorded by the exporting country and the value of imports recorded by the importing country is to be expected. The first reason is that in practice, statistical records used to report exports free-on-board (FOB), while imports value include cost-insurance and freight (CIF). This difference may drive a systematic difference between reported exports and imports, unrelated to tax-induced evasion. The second reason is that countries tend to monitor imports more carefully than exports. Thus, in the absence of tariff evasion one would expect the discrepancy to be negative. In the presence of import tariff evasion, discrepancies between source and destination trade data reported to Comtrade by national customs will thus reflect not just CIF/FOB differences and measurement error (Feenstra and Hanson, 2000), but also the extent of deliberate under-invoicing (Anson et al., 2003).

Stasarage and Daubrée (1998) report that a correct declaration of import's value does not prevent fraud from occurring, since the assessment of tax liabilities by customs officers can be purportedly incorrect; when taxes are correctly assessed commodities can also be released without the importer actually paying these taxes. In most cases, however, a customs duty evasion is rendered possible by false import declarations through four types of methods (Fisman \& Wei, 2004; Javorcik \& Narciso, 2007, Jean \& Mitaritonna, 2010). Underreporting of unit value, underreporting of taxable quantities, misclassification or mislabeling imported products from a higher-taxed to a lower-taxed type, and smuggling (Note 4). While different practices are involved in each case, each of this means of evading customs duties should lead to shipment registered by the importer being lower than those registered by the exporter, for high-tariff products (Jean \& Mitaritonna, 2010). Jean and Mitaritonna, 2010 emphasize that the link with tariffs may arise from the higher pay-off of escaping normal taxation in that case; it may also reflect the fact that finding a comparable product with substantially lower tariff is easier for product facing high tariffs.

\subsection{Types of Data and Data Sources}

The trade flow data for studying tax evasion is taken from the World Bank's World Integrated Trade Solution (WITS) data base, which in turn is derived from the United Nations' Comtrade database. These data are collected by the United Nations Statistical Division from individual countries' trade records, and include information on 
imports and exports for each country, recorded according to the Harmonized Commodity Description and Coding System (HS) at 6-digit category. The year used in this paper is 2012. The data on Tanzanian tariffs are taken from WITS, derived from the UNCTAD Trade Analysis and Information System (TRAINS) database and Tanzania Revenue Authority (TRA). The original sample of import from South Africa contained 2135 products in 2012 at the 6-digit classifications. However, there were missing observations for 488 classifications for either exports or imports, leaving a final sample of 1647. Regressions for tariff evasion involve fewer observations of imports from China (i.e. 271 commodities) due to missing observations on either exports and import values or export and import quantities or tariff rates.

\section{Empirical Results}

\subsection{Descriptive Analysis of Data}

Tables 4 and 5 summarize some characteristics of the variables used in the paper. One point to note is that the evasion gap has a positive mean when measured in values and it is more than the evasion gap measured in quantities of imports from China but it is less than the evasion gap measured in quantities from South Africa, generally, indicating that some evasion takes the form of underreporting of per unit values and quantities. An important difference between imports from the two major trading partners is the size of evasion gap. Trade gap is larger for imports from China than for imports from South Africa, when measured in both values and quantities. Table 4 reports that the mean trade gaps are 0.42 and 0.72 indices for imports from South Africa when measured in values and quantities respectively. These trade gaps are relatively less than 1.37 and 1.01 indices for imports from China, when measured in values and quantities respectively (Table 5). The mean tax rate of imports from China is 38.8 percent with maximum rate of 80 percent and a mean tax rate for imports from South Africa is 28.8 percent with the maximum rate of 60 percent. This shows that the average tax rate is higher for imports from China than for imports South Africa. This may suggest the reason for higher trade gap in trade data for imports from China than for imports from South Africa.

Table 4. Summary statistics, full sample: import from South Africa

\begin{tabular}{lrrrrr}
\hline Variable & Obs & Mean & Std. Dev. & Min & Max \\
\hline $\log (E V)$ & 1647 & 4.61 & 1.30 & 0 & 8.92 \\
$\log (I V)$ & 1647 & 4.18 & 1.30 & 0 & 7.69 \\
$G V$ & 1647 & 0.42 & 1.46 & -4.60 & 6.12 \\
$\log (E Q)$ & 1455 & 3.90 & 1.84 & 0 & 7.00 \\
$\log (I Q)$ & 1455 & 3.18 & 1.30 & 0 & 7.78 \\
GQ & 1455 & 0.72 & 1.55 & -5.24 & 6.10 \\
Tax rate(Tariff plus VAT) & 1647 & 28.85 & 9.92 & 10 & 60 \\
Avg(tax_o) (at HS4-digit) & 42 & 38.80 & 6.12 & 25 & 55 \\
\hline
\end{tabular}

Note. Summary statistics from balanced data, i.e. those observations containing data on both export and import values and quantities.

Table 5. Summary statistics, full sample: import from China

\begin{tabular}{lrrrrr}
\hline Variable & Obs & Mean & Std. Dev. & Min & Max \\
\hline $\log (E V)$ & 271 & 5.88 & 2.44 & 0 & 11.68 \\
$\log (I V)$ & 271 & 4.49 & 1.49 & 0.60 & 8.64 \\
$G V$ & 271 & 1.37 & 2.61 & -5.52 & 7.08 \\
$\log (E Q)$ & 271 & 5.45 & 2.44 & 0 & 12.76 \\
$\log (I Q)$ & 271 & 4.43 & 1.24 & 1.81 & 8.10 \\
$G Q$ & 271 & 1.01 & 2.51 & -4.75 & 6.24 \\
Tax rate(Tariff plus VAT) & 271 & 38.89 & 21.85 & 0 & 80 \\
Avg(tax_o) (at HS4-digit) & 123 & 41.51 & 7.46 & 0 & 69 \\
\hline
\end{tabular}

Note. Summary statistics from balanced data, i.e. those observations containing data on both export and import values and quantities.

\subsection{Regression Results}

In this section the empirical results are reported, based on the two regression equations discussed in the methodology section. The first issue to be analyzed is whether there is any correlation between trade gap (evasion gap), both in values and quantities, and tax rates in Tanzania, using imports from South Africa and China. The second issue is if the trade gaps are due to mislabeling of higher-taxed into lower-taxed products. 
The results for the degree of tax evasion in Tanzania in year 2012 using imports from South Africa and China are reported in Tables 6 and 7 respectively. Both Tables report that the tax rate coefficients are significant. Table 6 indicates that a one-percent point increase in the tax rate leads to a 0.12 percent increase in tax evasion when measured in import values from South Africa. Likewise, Table 7 suggests that a one-percent point increase in the tax rate leads to approximately 0.11 percent increase in tax evasion when measured in values of import from China.

Table 6. Imports from South Africa: the effect of tax rate on evasion (measured in value)

\begin{tabular}{ccccccc}
\hline Variable & Coef. & Std. Err. & $t$ & $\mathrm{p}>|t|$ & \multicolumn{2}{c}{$[95 \%$ Conf. Interval] } \\
\hline Tax Rate & 0.115 & 0.002 & $50.05^{* * *}$ & 0.000 & 0.110 & 0.119 \\
Constant & -2.878 & 0.069 & $-41.21^{* * *}$ & 0.000 & -3.016 & -2.741 \\
& Obs. & $=1647$ & \multicolumn{2}{c}{ Prob $>\mathrm{F}$} & $=0.000$ \\
& $\mathrm{~F}(1,1645)$ & $=2504.7$ & \multicolumn{2}{c}{ Adj R-squared } & $=0.603$ \\
\hline
\end{tabular}

Note. (i) ${ }^{* * *}$ Indicates significance at $1 \%$ level, ${ }^{* *}$ at $5 \%$ level, and $*$ at $10 \%$ level (ii) Dependent Variable: $\log$ (Value of Exports from Republic of South Africa to United Republic of Tanzania)-log (Value of Imports to Tanzania from South Africa).

Table 7. Imports from China: the effect of tax rate on evasion (measured in value)

\begin{tabular}{ccccccc}
\hline Variable & Coef. & Std. Err. & $t$ & $\mathrm{p}>|t|$ & \multicolumn{2}{c}{$[95 \%$ Conf. Interval] } \\
\hline Tax Rate & 0.109 & 0.002 & $39.11^{* * *}$ & 0.000 & 0.104 & 0.115 \\
Constant & -2.874 & 0.125 & $-22.99^{* * *}$ & 0.000 & -3.120 & -2.627 \\
& Obs & $=271$ & \multicolumn{2}{c}{ Prob $>\mathrm{F}$} & $=0.000$ \\
& $\mathrm{~F}(1,269)$ & $=1529.66$ & & Adj R-squared & $=0.849$ \\
\hline
\end{tabular}

Note. (i) ***Indicates significance at $1 \%$ level, ** at $5 \%$ level, and * at $10 \%$ level (ii) Dependent Variable: $\log$ (Value of Exports from China to United Republic of Tanzania)-log (Value of Imports to Tanzania from China).

The adjusted R-squared is larger in the tax evasion regression analysis using imports from China than South Africa indicating that variations in the trade gaps (measured in values) in Tanzania is more explained by import tax rate from China than South Africa.

In addition to underreporting of the value of imports, evasion can also take the form of mislabeling a higher taxed product as a lower taxed similar variety. If misclassification takes place one would expect the coefficient on tax on similar products to be negative, which would signify a lower tariff on similar products creates more opportunity for misreporting. Tables 8 and 9 report the results with average tax rate on similar products, $\operatorname{Avg}\left(\operatorname{Tax} \_\right.$o), included as a regressor. Table 8 shows that, consistent with the mislabeling interpretation, the coefficient on $\operatorname{Avg}\left(\operatorname{Tax} \_\right)$is negative and significant at the 10 percent level, when using import values from South Africa. Furthermore, the inclusion of the average tax rate of similar goods as a regressor results in a substantial increase in the coefficient on tax rate, which takes on value of 0.75 .

Table 8. Incorporating the average tax on similar products (measured in values) import from Republic of South Africa

\begin{tabular}{ccccccc}
\hline Variable & Coef. & Std. Err. & $t$ & \multicolumn{2}{c}{$\mathrm{p}>|t|$} & \multicolumn{2}{c}{$[95 \%$ Conf. Interval] } \\
\hline Tax Rate & 0.750 & 0.093 & $8.00^{* * *}$ & 0.000 & 0.560 & 0.939 \\
Avg(tax_o) & -0.102 & 0.055 & $-1.84 *$ & 0.073 & -0.215 & 0.009 \\
Constant & -15.044 & 2.445 & $-6.12^{* * *}$ & 0.000 & -20.012 & -10.074 \\
& Obs & $=42$ & \multicolumn{2}{c}{ Prob $>\mathrm{F}$} & $=0.000$ \\
& $\mathrm{~F}(2,38)$ & $=35.49$ & \multicolumn{3}{c}{ Adj R-squared } & $=0.627$ \\
\hline
\end{tabular}

Note. (i) ${ }^{* * *}$ Indicates significance at $1 \%$ level, ${ }^{* *}$ at $5 \%$ level, and $*$ at $10 \%$ level (ii) Dependent Variable: $\log$ (Value of Exports from Republic of South Africa to United Republic of Tanzania)-log (Value of Imports to Tanzania from Republic of South Africa). 
Table 9. Incorporating the average tax on similar products (measured in values): imports from China

\begin{tabular}{ccccccc}
\hline Variable & Coef. & Std. Err. & $t$ & $\mathrm{p}>|t|$ & {$[95 \%$ Conf. Interval] } \\
\hline Tax Rate & 0.107 & 0.003 & $30.22^{* * *}$ & 0.000 & 0.100 & 0.114 \\
Avg(tax_o) & 0.002 & 0.012 & 0.23 & 0.817 & -0.021 & 0.027 \\
Constant & -2.796 & 0.553 & $-5.05 * * *$ & 0.000 & -3.892 & -1.699 \\
& Obs & $=123$ & \multicolumn{2}{c}{ Prob $>\mathrm{F}$} & $=0.000$ \\
& $\mathrm{~F}(2,120)$ & $=466.4$ & Adj R-squared & $=0.884$ \\
\hline
\end{tabular}

Note. (i) $* * *$ Indicates significance at $1 \%$ level, $* *$ at $5 \%$ level, and $*$ at $10 \%$ level (ii) Dependent Variable: log (Value of Exports from China to United Republic of Tanzania)-log (Value of Imports to Tanzania from China).

When tax on similar products is included as regressor into the tax evasion equation using imports from china, the results show that tariff on similar products does not appear to be statistically significant. These results indicate that mislabeling (at least within the same 4-digit HS category) is not widespread in the trade data between China and Tanzania.However, the overall responsiveness of trade gap to the tariff rate retains its significance.

When estimating evasion on imports using physical quantities, Tables 10 and 11 show that one-percent point increase in the tax rate leads to a 0.11 percent and 0.10 percent increase in tax evasion when using physical quantities of imports from the Republic of South Africa and China respectively.

Table 10. Imports from Republic of South Africa: the effect of tax rate on evasion (measured in physical quantity)

\begin{tabular}{ccccccc}
\hline Variable & Coef. & Std. Err. & $t$ & $\mathrm{p}>|t|$ & \multicolumn{2}{c}{ [95\% Conf. Interval] } \\
\hline Tax Rate & 0.112 & 0.002 & $40.68^{* * *}$ & 0.000 & 0.107 & 0.118 \\
Constant & -2.606 & 0.086 & $-30.14 * * *$ & 0.000 & -2.776 & -2.4372 \\
& Obs & $=1455$ & \multicolumn{2}{c}{ Prob $>\mathrm{F}$} & $=0.000$ \\
& $\mathrm{~F}(1,1645)$ & $=1654.8$ & & Adj R-squared & $=0.532$ \\
\hline
\end{tabular}

Note. (i) ***Indicates significance at $1 \%$ level, ** at $5 \%$ level, and * at $10 \%$ level (ii) Dependent Variable: log (Quantity of Exports from Republic of South Africa to United Republic of Tanzania)-log (Quantity of Imports to Tanzania from Republic of South Africa).

Table 11. Imports from China: the effect of tax rate on evasion (measured in physical quantity)

\begin{tabular}{ccccccc}
\hline Variable & Coef. & Std. Err. & $t$ & $\mathrm{p}>|t|$ & {$[95 \%$ Conf. Interval] } \\
\hline Tax Rate & 0.104 & 0.002 & $35.26^{* * *}$ & 0.000 & 0.098 & 0.110 \\
Constant & -3.042 & 0.131 & $-23.07^{* * *}$ & 0.000 & -3.302 & -2.782 \\
& Obs & $=271$ & \multicolumn{2}{c}{ Prob $>\mathrm{F}$} & $=0.000$ \\
& $\mathrm{~F}(1,1645)$ & $=1243.2$ & & Adj R-squared & $=0.821$ \\
\hline
\end{tabular}

Note. (i) ***Indicates significance at $1 \%$ level, ** at $5 \%$ level, and * at $10 \%$ level (ii) Dependent Variable: log (Quantity of Exports from China to United Republic of Tanzania)-log (Quantity of Imports to Tanzania from China).

When using $G Q$ as the dependent variable, interestingly, when $A v g\left(\operatorname{Tax} \_\right.$) is included into the regression, the coefficient on tax rate is significantly different from zero and the coefficient on $A v g\left(\operatorname{Tax} \_\right.$) is negative and significant at 10 percent for imports from South Africa (Table 12).

When using physical quantities of import data from China, regression results reported in Table 13 suggest that mislabeling a higher-taxed product as a lower-taxed product is not present. Generally, empirical results on tax rate and tax evasion show that first; there is evidence of underreporting in values and in quantities in the trade flow between Republic of South Africa and United Republic of Tanzania, on one hand and China and United Republic of Tanzania on the other. The evasion gap is positively correlated with tax rate, implying that any increase in tax rate is likely to produce a reduction rather than an increase in tax revenue. This result confirms the study by Osoro (1993) who reveals that, the major causes of tax evasion in Tanzania have been high tax rates that led to high tax bills or tax burdens.Second, tax evasion takes a form of misclassification in imports from Republic of South Africa but it does not take the form of mislabeling from a higher taxed product to a lower taxed variety in imports from China. 
Table 12. Incorporating the average tax on similar products (measured in quantity): import from Republic of South Africa

\begin{tabular}{ccccccc}
\hline Variable & Coef. & Std. Err. & $T$ & $\mathrm{p}>|t|$ & \multicolumn{2}{c}{$[95 \%$ Conf. Interval] } \\
\hline Tax Rate & 0.536 & 0.054 & $9.92^{* * *}$ & 0.000 & 0.426 & 0.645 \\
Avg(tax_o $)$ & -0.752 & 0.039 & $-1.90^{*}$ & 0.066 & -0.155 & 0.005 \\
Constant & -10.746 & 1.823 & $-1.89^{* * *}$ & 0.000 & -14.440 & -7.051 \\
& Obs & $=40$ & \multicolumn{2}{c}{ Prob $>\mathrm{F}$} & $=0.000$ \\
& $\mathrm{~F}(2,37)$ & $=50.5$ & & Adj R-squared & $=0.717$ \\
\hline
\end{tabular}

Note. (i) ***Indicates significance at $1 \%$ level, $* *$ at $5 \%$ level, and $*$ at $10 \%$ level (ii) Dependent Variable: log (Quantity of Exports from Republic of South Africa to United Republic of Tanzania)-log (Quantity of Imports to Tanzania from Republic of South Africa).

Table 13. Incorporating the average tax on similar products (measured in quantity): import from China

\begin{tabular}{ccccccc}
\hline Variable & Coef. & Std. Err. & $T$ & $\mathrm{p}>|t|$ & \multicolumn{2}{c}{$[95 \%$ Conf. Interval] } \\
\hline Tax Rate & 0.111 & 0.005 & $21.63 * * *$ & 0.000 & 0.100 & 0.121 \\
Avg(tax_o) & 0.012 & 0.017 & 0.73 & 0.469 & -0.022 & 0.048 \\
Constant & -4.062 & 0.801 & $-5.07 * * *$ & 0.000 & -5.650 & -2.475 \\
& Obs & $=123$ & \multicolumn{2}{c}{ Prob $>\mathrm{F}$} & $=0.000$ \\
& $\mathrm{~F}(2,120)$ & $=237.4$ & Adj R-squared & $=0.794$ \\
\hline
\end{tabular}

Note. (i) $* * *$ Indicates significance at $1 \%$ level, $* *$ at $5 \%$ level, and $*$ at $10 \%$ level (ii) Dependent Variable: log (Quantity of Exports from China to United Republic of Tanzania)-log (Quantity of Imports to Tanzania from China).

\section{Conclusions}

This paper empirically examined tax rates as the determinants of tariff revenue evasion across products, based on a systematic analysis of discrepancies in trade declarations for trading partners. The paper adopted an approach by Fisman and Wei (2004) in measuring the effect of tax rates on tax evasion by looking at the reporting gap in Tanzania's imports from South Africa and China as a function of Tanzanian tax rates (tariff plus VAT rates). The paper focused on two issues. The first is whether there is any correlation between tax evasion, as reported by the trade gap and the tax rate in Tanzania. This was done in two ways, whereas in the first, the study utilized data on exports and imports reported in values and in the second, the study utilized data on imports and exports reported quantities. The second issue is that whether the trade gap is due to mislabeling a higher-taxed products as a lower-taxed product, utilizing both value and quantity data.

The results indicated that evasion "gap" is highly correlated with tax rates, i.e. much more value is lost for products with higher tax rates. To avoid the heavy tax burden some potential and actual taxpayers have decided to go underground. The results also showed that the evasion gap is correlated with tax rates on closely rated products from Republic of South Africa, implying that evasion takes place through misclassification of imports from higher-taxed categories to lower-taxed ones. However, there was no evidence of misclassification of imports from China.

Tax evasion is the basic characteristic of many developing countries. De facto tax collections are consequently far below revenue implied by published or de jure tax rates. Efforts to address this problem have therefore been a key component of economic reform programmes geared at macroeconomic stabilization and promoting a better balance in public finances. The wide divergences between the effective and statutory tax rates in Tanzanian tax system indicate that there is a scope for raising tax revenue without increasing tax rates by reinforcing tax and customs administrations and reducing tax evasion. Since high tariff rates make import under-valuation more lucrative, reduction in duty rates is a possible solution. However, Tanzania, which depends greatly on import taxes, may find it difficult to reduce duties beyond a point in the short-run, though reduction in duty can be partly compensated by way of greater yield from the resultant larger volume of imports at lower rates.

\section{Acknowledgments}

The author thanks Prof. Nehemiah Osoro and Prof. Michael O. Ndanshau for their valuable comments.

\section{References}

Acharya, S. (1985). Aspects of the Black Economy in India. Government of India, New Delhi.

Allingham, M. G., \& Sandmo, A. (1972). Income Tax Evasion: A Theoretical Analysis. Journal of Public 
Economics, (1), 323-338. http://dx.doi.org/10.1016/0047-2727(72)90010-2

Anson, J., Olivier, C., \& Marcelo, O. (2003). Tariff Evasion: Does PSI Help? World Bank Research Programme on customs Corruption and Pre-Shipment Inspection Service.

Basu, P., \& Oliver, M. (1993). The Fiscal Impact of Adjustment in Tanzania in the 1980s. Nottingham: CREDIT/University of Nottingham.

Bhagwati, J. N. (1967). The Tying of Aid. UNACTAD Secretariat, TD/7/8 Supp. 4, United Nations, 1-57.

Bhagwati, J. N. (1994). Threats to the World Trading System: Income Distribution and the Selfish Hegemon. Columbia University, Department of Economics Working Paper No. 696.

Di, J. J. (2010). The Political Economy of Taxation and State Resilience of Zambia since 1990. Crisis Study Working Paper (Series 2) 75, London, London School of Economics.

Ebrill, L., Janet, S., \& Reint, G. (1999). Revenue Implications of Trade Liberalization. International Monetary Fund Occasional Paper, 180. http://dx.doi.org/10.5089/9781557758026.084

Economic and Social Research Foundation. (1996). Aid Effectiveness in Tanzania: The Case of Danish Aid. Policy Dialogue Series No. 007.

Fisman, R., \& W, S. J. (2004). Tax Rates and Tax Evasion: Evidence from Missing Imports in China. Journal of Political Economy, 112(2), 471-496. http://dx.doi.org/10.1086/381476

Fjeldstad, O. H. (2002). Fighting Fiscal Corruption: The Case of the Tanzania Revenue Authority. Chr. Michelsen Institute Development Studies and Human Rights.

Fjeldstad, O. H., \& Lise, R. (2003). Taxation and Tax Reforms in Developind Countries: Illustration from sub-Saharan Africa. Chr. Michelsen Institute Development Studies and Human Rights.

Gutmann, P. M. (1977). The Subterranean Economy. Financial Analyst Journal, 33(6), $26-34$. http://dx.doi.org/10.2469/faj.v33.n6.26

Harberger, A. C. (1964). Principles of Efficiency: The Measurement of Waste.American Economic Review, 54, $58-76$.

International Monetary Fund. (2005). Dealing with the Revenue Consequences of Trade Reform. Fiscal Affairs Department, IMF.

Javorcik, B., \& Gaia, N. (2008). Differentiated Products and Evasion of Import Tariffs. Journal of International Economics, 76(2), 208-222. http://dx.doi.org/10.1016/j.jinteco.2008.07.002

Jean, S., \& Christina, M. (2010). Determinants and Pervasiveness of the Evasion of Customs Duties. CEPII, WP No. 2010-20.

Johnson, S., Daniel, K., \& Andrei, S. (1997). The Unofficial Economy in Transition. Brookings Papers on Economic Activity, Fall, Washington D.C. http://dx.doi.org/10.2307/2534688

Johnson, S., Daniel, K., \& Pablo, Z. L. (1998a). Regulatory Discretion and the Unofficial Economy. The American Economic Review, 88(2), 387-392.

Johnson, S., Daniel, K., \& Pablo, Z. L. (1999). Corruption, Public Finances, and the Unofficial Economy. The World Bank Policy Working Paper, Series 2169, Washington D.C.

Levin, J., \& Lars, M. W. (2007). Tax Evasion in Kenya and Tanzania: Evidence from Missing Imports. Department of Business, Economics, Statistics, and Informatics, University of Örebro.

Luoga, F. (2002). Taxpayers' Rights in the Context of Governance: Tanzania. IDS Bulletin, 33(3), $50-57$. http://dx.doi.org/10.1111/j.1759-5436.2002.tb00031.x

Maliyamkono, T. L., \& Bagachwa, M. S. D. (1990). TheSecond Economy in Tanzania. USA: Ohio University Press.

Mpango, P. I. (1996). Evasion of Import Duties: An Economic Analysis of the Case of Tanzania. Ph.D. Thesis, University of Dar es Salaam.

Osoro, E. N. (1990). The Revenue Generating Potential of the Tanzanian Tax System. Tanzania Journal of Economics, 1, 53-62.

Osoro, E. N. (1993). Revenue Productivity Implication of Tax Reform in Tanzania. African Economic Research Consortium (AERC), Research Paper No. 20. 
Osoro, E. N. (1995). Tax Reforms in Tanzania: Motivations, Directions and Implications. African Economic Research Consortium (AERC), Research Paper No. 38.

Osoro, E. N., Philip, I., Mpango, N., \& Hamis, H. M. (1999). Enahancing Transparency in Tax Administration in Tanzania. EAGER/PSGE Research Report 10719, Department of Economics, University of Dar es Salaam, Dar es Salaam.

Pritchett, L., \& Geeta, S. (1994). Tariff Rates, Tariff Revenues, and Tariff Reform: Some New Facts. World Bank Economic Review, 8(1), 1-16. http://dx.doi.org/10.1093/wber/8.1.1

Schneider, F., \& Christopher, B. (2003). The Size and the Development of Shadow Economies in the Asia-Pacific. Department of Economics, Johannes Kepler University Linz, Working Paper No. 0301.

Schneider, F., \& Dominik, E. (2000). Shadow Economies: Size, Causes, and Consequences. The Journal of Economic Literature, 38(1), 77-114. http://dx.doi.org/10.1257/jel.38.1.77

Sébastien, J., \& Cristina, M. (2009). Determinants and Pervasiveness of the Evasion of Custom Duties. (UMR ECONOMIE PUBLIQUE INRA-AGROPARISTECH AND CEPII).

Slemrod, J., \& Shlomo, Y. (2000). Tax Avoidance, Evasion, and Administration. NBER Working Papers No, 7473, National Bureau of Economic Research, Inc.

Stasavage, D., \& Daubree, C. (1998). Determinants of Customs Fraud and Corruption: Evidence from Two African Countries. Working Paper No. 138, OECD Development Centre, Organization for Economic Co-operation and Development, Paris.

Tanzania, Revenue Authority (TRA). (n.d.). Revenue Performance Reports. Dar es Salaam: Tanzania Revenue Authority.

Tanzi, V. (1980). The Underground Economy in the United States: Estimates and Implications. Banca Nazionale de Lavoro Quarterly Review, 135, 427-453.

Tanzi, V. (2003). Trade Liberalization and Trade Tax. A Note Prepared for the Meeting of Trade and Integration Network.

Van Dunem, J., \& Arndt, C. (2009). Estimating the Elasticity of Evasion. Journal of Development Studies, 45 , 1010-1025. http://dx.doi.org/10.1080/00220380902952324

World Bank. (1996). The Challenge of Reforms: Growth, Incomes, and Welfare. Country Operation Division, East Africa Department Report No. 14982-TA, Vol. 2: Appendices and Statistics.

Yitzhaki, S. (1974). Income Tax Evasion: A Theory Analysis. Journal of Public Economics, 3, $201-202$. http://dx.doi.org/10.1016/0047-2727(74)90037-1

\section{Notes}

Note 1. The paper considered South Africa, China, and UAE as major trading partners to Tanzania.

Note 2. Ebrill, L., J. Stotsky, and R. Gropp (1999) and Pritchett, L., and G. Sethi (1994) define collected tariff rate as the ratio of import duties to the value of imports. The measure is based on how much tariff revenue is actually collected.

Note 3. The ideal way to measure the gap is to use import values and exports values exclusive of CIF/FOB. However, by regressing gap_qty on tax rate this problem is circumvented and this results in similar $\lambda$-values. In the cases where values are used instead of quantities, the CIF-FOB problem creates a gap value, but there is no reason why it should be correlated with the tax rate.

Note 4. Smuggling is generally defined as imports crossing the border without being registered by customs officers. Smuggling may not be registered even in the exporter statistics; however, exports are duly by the exporters (Jean \& Mitaritonna, 2010).

\section{Copyrights}

Copyright for this article is retained by the author(s), with first publication rights granted to the journal.

This is an open-access article distributed under the terms and conditions of the Creative Commons Attribution license (http://creativecommons.org/licenses/by/3.0/). 